\title{
ANALISIS ALTERNATIF DALAM MERANCANG BALOK TINGGI MENGGUNAKAN STRUT AND TIE MODEL
}

\author{
Nisa Luthfiana ${ }^{1)}$, Yulita Arni Priastiwi ${ }^{2)}$ \\ Departemen Teknik Sipil, Universitas Diponegoro, Semarang \\ nisaluthfiana0@gmail.com ${ }^{l)}$,yulita tiwi@ymail.com ${ }^{2)}$
}

DOI: http://dx.doi.org/10.29103/tj.v11i1.393

(Received: September 2020 / Revised: January 2021 / Accepted: January 2021)

\begin{abstract}
Abstrak
Perencanaan struktur beton biasanya dilakukan dengan berdasarkan asumsi dari Bernoulli dan Navier untuk menganalisis penampang akibat momen lentur. Distribusi regangan dianggap linier dan ini dianggap masih berlaku meskipun penampang telah retak. Balok tinggi merupakan salah satu contoh kasus pada suatu elemen struktur yang dapat mengakibatkan terjadinya distribusi tegangan non linier, sehingga asumsi diatas tidak berlaku. Balok dikatakan balok tinggi apabila rasio bentang terhadap tingginya lebih kecil dari lima. Salah satu alternatif pendekatan untuk mengatasi elemen struktur seperti balok tinggi adalah menggunakan pendekatan Strut and Tie Model, yaitu dengan membagi struktur dalam daerah B (Bernoulli) dan D (Disturb) dan menggambarkan alur gaya (load path) sebagai transfer gaya yang terjadi pada struktur beton bertulang pada kondisi retak akibat pembebanannya. Parameterparameter dari Strut and Tie Model yaitu batang tekan (strut), batang tarik (tie) dan titik nodal (nodal zone) sebagai daerah pertemuan. Tujuan dari tulisan ini adalah untuk menganalisis alternatif perencanaan/desain tulangan struktur balok tinggi beton bertulang diatas dua tumpuan sederhana akibat beban merata yang dikonversi menggunakan beban terpusat 2 titik pembebanan.Metode yang digunakan adalah Strut and Tie Model yang akan menghasilkan luas tulangan longitudinal yang lebih kecil dengan selisih $25 \%$, di mana dengan luas tulangan yang lebih kecil dari segi kekuatan masih memenuhi syarat. Hal ini menunjukkan bahwa perhitungan perencanaan balok tinggi tanpa bearing plate dengan menggunakan metode Strut and Tie Model pun dapat lebih optimum/efisien.
\end{abstract}

Kata kunci: Prinsip Bernoulli, Strut and Tie Model, D - Region, B - Region

\begin{abstract}
Concrete structure planning is usually carried out based on the assumptions of Bernoulli and Navier to analyze the section due to bending moments. The strain distribution is considered linear and it is considered still valid even after the section has cracked. The deep beam is one example of a structural element that can result in a non-linear stress distribution, so the above assumption does not apply. A beam is said to be a deep beam if the span to height ratio is less than five. One alternative approach to dealing with structural elements such as deep beams is to use the Strut and Tie Model approach, namely by dividing the structure into areas B (Bernoulli) and D (Disturb) and describing the load path as a force transfer that occurs in the concrete structure. Reinforced in cracked conditions due to loading. The parameters of the Strut and Tie Model are the strut, tie, and nodal zone as the meeting area. The purpose of this paper is to analyze the alternative planning/design of reinforced concrete beams structure on two simple supports due to evenlydistributed loads that are
\end{abstract}

Analisis Alternatif Dalam Merancang Balok Tinggi Menggunakan Strut And Tie Model Nisa Luthfiana, YulitaArniPriastiwi 
converted using the two-point load centered load. The method used is the Strut and Tie Model which will produce a smaller area of longitudinal reinforcement with a difference of $25 \%$, where the area of reinforcement is smaller in terms of strength still meets the requirements. This shows that the calculation of deep beam planning without bearing plate using the strut and tie model method can be more optimal/efficient.

Keywords: Bernoulli's Principle, Strut and Tie Model, D - Region, B - Region

\section{Latar Belakang}

Secara umum, prosedur perancangan suatu struktur bangunan harus menjamin bahwa di bawah kondisi pembebanan terburuk struktur harus tetap aman, dan selama kondisi kerja normal deformasi dari bagian-bagian struktur tidak mengurangi bentuk, keawetan dan penampilan dari struktur, walaupun sulit untuk menaksir akibat pembebanan yang tetap dengan kekuatan beton dan baja yang bervariasi, ketentuan diatas harus tetap dipenuhi.

Perencanaan struktur beton berdasarkan analisis batas (limit analysis) yang telah diselidiki melalui penelitian (Misbakhul Munir and Zulfikar Djauhari, 2014) bahwa selama hampir empat dasawarsa belakangan ini, distribusi regangan dianggap linier dan ini dianggap masih berlaku meskipun penampang telah retak. Banyaknya kasus untuk elemen struktur yang memiliki bentuk cukup rumit akan menimbulkan suatu permasalahan dalam perancangan, hal ini terjadi pada elemen-elemen struktur seperti balok tinggi, corbel, dan sebagainya yang dapat mengakibatkan terjadinya distribusi regangan - non linier sehingga tidak dapat lagi direncanakan dengan cara standar. Perencanaan yang dilakukan kadang kala hanyalah bersifat pendekatan dengan peraturan-peraturan standar yang ada walaupun kadang terjadi perbedaan yang signifikan. Salah satu alternatif pendekatan untuk mengatasinya adalah menggunakan pendekatan strut and tie model.

Seperti pada penelitian (Saputra and Satuan, 2012) bahwa metode strut and tie dirumuskan terhadap keadaan batas (ultimate limit state) karena adanya retak elemen beton pada daerah tekan yang akan mengurangi kekuatan beton. Pengembangan dalam perancangan struktur beton bertulang dengan strut and tie model, yaitu dengan membagi struktur dalam daerah $\mathrm{D}$ dan $\mathrm{B}$ serta menggambarkan alur gaya (load path) sebagai transfer gaya yang terjadi pada struktur beton bertulang, pada kondisi retak dari sumber pembebanannya sampai tumpuan. Daerah B adalah suatu daerah di mana hipotesa Bernoulli berlaku, yaitu di mana penampang dianggap rata dan tegak lurus garis netral sebelum dan sesudah lentur. Daerah D adalah bagian dari struktur di mana terdapat/terjadi beban merata, seperti bukaan, perubahan penampang dan lain-lain yang menyebabkan kondisi kompleks dari keadaan regangan di sekitarnya. Berdasarkan penelitian yang sudah dilakukan oleh (Afrizal, 2011) dan dapat dijelaskan bahwa strut-and tie model adalah sebuah model struktur rangka dari suatu elemen struktural atau dari sebuah D-region dalam elemen tersebut, yang terdiri dari batang-batang desak dan batang-batang tarik yang terhubung pada titik-titik nodal, dan yang mampu meneruskan beban-beban terfaktor ke titik-titik tumpuan atau ke B-region di dekatnya (ACI-318, 2019). Pada Gambar 1 ditunjukkan pembagian daerah D dan B pada balok akibat beban merata. 


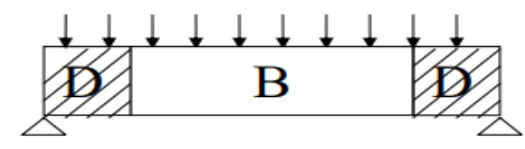

Gambar 1 Pembagian daerah D dan B pada balok

Struktur seperti balok tinggi (deep beam) mengandung daerah D (ACI318, 2019) menjelaskan bahwa suatu balok dinyatakan sebagai balok tinggi dalam perancangan lentur bila rasio bentang bersih balok dibandingkan dengan tinggi balok $l_{n} / d \leq 1,25$ untuk di atas dua tumpuan dan $l_{n} / d \leq 2,5$ untuk balok di atas beberapa tumpuan. Selanjutnya balok juga dinyatakan sebagai balok tinggi dalam perancangan geser bila $l_{n} / d \leq 5,0$ dan balok tersebut dibebani dari permukaan atas serta ditumpu pada sisi bawah balok. Mekanisme geser yang bekerja pada balok tinggi seperti pada penelitian (Agus Sugianto, 2014) merupakan hal yang sangat penting untuk diperhatikan. Definisi tentang suatu balok yang dinyatakan sebagai balok tinggi apabila sebagian besar beban yang dipikul dapat diteruskan atau dihubungkan langsung ke tumpuan-tumpuannya melalui batang tekan (compression test). Gambar 2 menunjukkan contoh suatu balok tinggi di atas 2 perletakan.

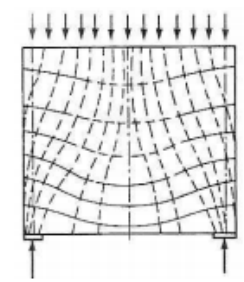

Gambar 2 Balok tinggi beban merata di atas dua perletakan

Tujuan tulisan ini adalah untuk menganalisis alternatif dari perencanaan/desain balok tinggi dengan menggunakan strut and tie model dengan menggunakan beban merata yang dikonversi menjadi beban 2 titik terpusat. Sedangkan manfaat dari penelitian ini adalah untuk memperoleh kebutuhan tulangan pada balok tinggi dengan metode strut and tie model.

\section{Metode Penelitian}

Metode penelitian yang digunakan adalah dengan menganalisis secara manual desain balok tinggi dengan metode strut and tie model untuk menentukan kebutuhan tulangan yang diperlukan.

Perencanaan balok tinggi seperti diuraikan pada perhitungan di mana diketahui data-data sebagai berikut:

$$
\begin{array}{ll}
\text { Panjang balok }(\mathrm{L}) & =6000 \mathrm{~mm} \\
\text { Selimut beton }(\mathrm{s}) & =50 \mathrm{~mm} \\
\text { Bentang rangka balok }\left(\ell_{n}\right) & =\mathrm{L}-2 \times \mathrm{s}=6000-2 \times 50=5900 \mathrm{~mm} \\
\text { Tinggi balok }(\mathrm{H}) & =800 \mathrm{~mm} \\
\text { Dengan peraturan }(\mathrm{ACI} 318,2019) & =300 \mathrm{~mm} \\
\text { Diambil Lebar balok }\left(b_{w}\right) & =40 \mathrm{MPa} \\
f_{c}^{\prime} & =400 \mathrm{MPa} \\
f_{y 1} & =340 \mathrm{MPa}
\end{array}
$$


Beban merata $(\mathrm{Q})$

Beban terpusat (2P)

D tulangan tarik

$\varnothing$ tulangan geser horizontal

$\varnothing$ tulangan geser vertikal
$=95 \mathrm{kN} / \mathrm{m}$, beban dikonversi ke beban terpusat

$=570 \mathrm{kN}$

$=16 \mathrm{~mm}$

$=10 \mathrm{~mm}$

$=10 \mathrm{~mm}$

Dari data-data yang ada, beban yang dikonversi menjadi beban terpusat dimaksudkan untuk memudahkan dalam melakukan perhitungan. Menurut persamaan yang mengacu ke penelitian yang sudah dilakukan (Simatupang and Cendana, 2017) bahwa perancangan balok tinggi bahwa beban merata yang digunakan juga dikonversi menjadi 2 titik pembebanan.

Pada suatu struktur, umumnya hanya terdapat beberapa bentuk standar, karena itu dapat dibuat analisis yang lebih mendasar dan mendetail untuk menentukan model standar yang dapat diterapkan pada bentuk yang sama dengan ukuran yang berbeda. Standarisasi ini dapat memudahkan pekerjaan seseorang perencana dan menghindari variasi penggunaan model oleh perencana yang berbeda. Model elemen dan jenis pembebanan pada penelitian ini adalah seperti ditunjukkan dalam Gambar 3.

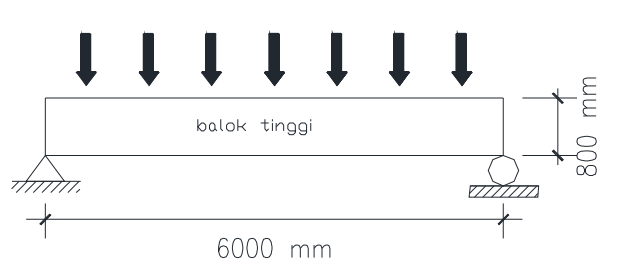

Gambar 3 Detail elemen balok tinggi yang memperlihatkan jenis perletakan

Langkah-langkah dalam melakukan perhitungan pemodelan balok tinggi dengan strut and tie model adalah sebagai berikut:

a. Mencari gaya reaksi bisa dilakukan dengan pengecekan gaya batang yang bekerja pada nodal. Salah satunya yaitu dengan mencari tinggi nodal (dari bangun geometri rangka dan gaya-gaya yang bekerja padanya)

$$
d_{v}=H-\frac{(\text { t.nodal } A+\text { t.nodal C }}{2}
$$

b. Memeriksa daerah nodal dan kekuatan batang strut

- Mencari kekuatan efektif $\left(f_{\mathrm{cu}}\right)$ pada nodal A (cek nodal)

$$
f_{c u}=0,85 x \beta_{n} x f_{c}
$$

- Menghitung lebar daerah batang Tarik (Wn)

$$
W_{n}=\frac{F_{A F}}{\Phi x b_{w} x F_{c u}} \leq 0,2 H
$$

- Mencari panjang pelat landasan (lb)

$$
l b_{n} \approx W_{n}
$$

- Mencari besar nilai tegangan yang terjadi pada dasar nodal $\left(f_{\mathrm{basic}}\right)$

$$
f_{\text {basic }}=\frac{R_{x}}{b_{w} x l b}
$$


- Mengecek kekuatan batang strut

$$
F_{c u(s t r u t)}=0,85 x \beta_{s} x f_{c}
$$

di mana $\beta_{s}=0,75_{c}$

- Mencari lebar batang strut

$$
W_{n}=\left(W_{n}\right)(\operatorname{Cos} \theta)+\left(1 b_{n}\right)(\operatorname{Sin} \theta)
$$

- Lakukan langkah pengecekan nodal pada nodal yang lain. Langkahnya sama dengan cara mengecek pada nodal A

c. Memeriksa gaya geser maksimum yang dizinkan pada balok tinggi (ACI318, 2019)

- Menentukan batas gaya geser yang diizinkan

$$
d=h-\frac{W_{n}}{2}
$$

- Untuk menentukan gaya geser yang diizinkan

$$
V_{u}<\Phi\left|\frac{2}{3}\left(10+\frac{l_{n}}{d}\right) \sqrt{f_{c} b_{w} d}\right|
$$

d. Menentukan penulangan yang digunakan pada batang tie

$$
A_{s \text { perlu }}=\frac{F_{A F}}{\Phi x f_{y}^{\prime}}
$$

sedangkan pada (ACI318, 2019) untuk penulangan $\mathrm{A}_{\mathrm{s} \text { perlu }}$ pada daerah tarik tidak kurang dari $0,04\left(\frac{f_{c}}{f_{y}}\right) b_{w} \cdot d$

e. Menghitung critical section $\left(1_{a}\right)$

- Mengecek jarak critical section $\left(1_{\mathrm{a}}\right)$

$$
l_{s}=\left(\frac{W_{16}}{2}\right) / \tan \theta
$$

- Mengecek panjang penyaluran (SNI03-2847, 2019)

$$
L_{d h}=\frac{f_{y} x d_{b}}{5,4 x \sqrt{f_{c}^{\prime}}}>8 d_{b}
$$

- Memberi penulangan minimum pada batang strut

- Menghitung besar sudut vertikal dengan aksis pada batang strut

$$
\rho_{v}=\frac{4 . \pi \cdot r^{2}}{s_{v} b_{w}}>0,0015
$$

- Menghitung besar sudut horisontal dengan aksis pada batang strut

$$
\rho_{h}=\frac{2 . \pi \cdot r^{2}}{s_{h} b_{w}}>0,0015
$$

f. Cek persyaratan $(\mathrm{ACI} 318,2019)$

$$
\sum(\rho i)(\sin \gamma)>0,003
$$

g. Penggambaran detail balok tinggi hingga penulangannya 


\section{Hasil dan Pembahasan}

Dalam penelitian ini disajikan hasil-hasil yang akan dibahas sesuai dengan focus sebagai berikut:

a. Bangun Geometri rangka dan gaya-gaya yang bekerja (lihat Gambar 4)

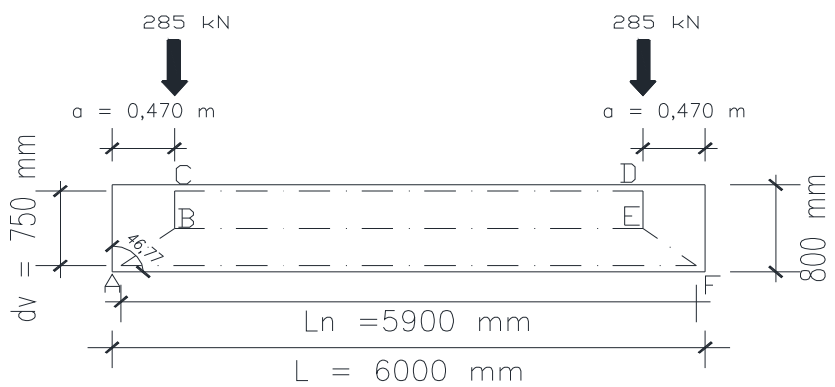

Gambar 4 Rangka batang untuk balok tinggi

Dengan asumsi tinggi nodal $\mathrm{A}=50 \mathrm{~mm}$ dan tinggi nodal $\mathrm{C}=50 \mathrm{~mm}$, maka dicari tinggi rangka yang terbentuk (dv). Seperti diperlihatkan pada Gambar 5 untuk posisi asumsi nodalnya

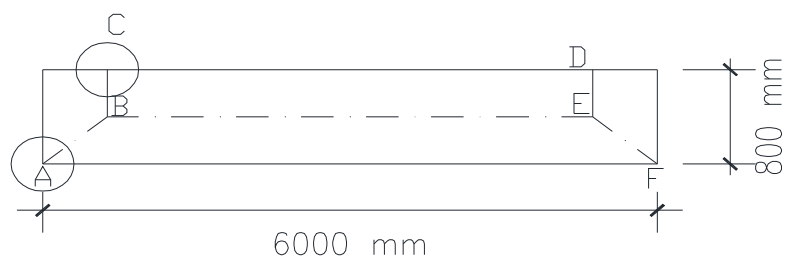

Gambar 5 Asumsi posisi nodal

$$
\mathrm{dv}=\mathrm{II}-\frac{(\mathrm{t} \text {. nodal } \mathrm{A}+\mathrm{t} \text { nodal C)}}{2}=800-\frac{(50+50)}{2}=750 \mathrm{~mm}
$$

Untuk mencari nilai sudut yang dibentuk truss, dicari jarak antara batang AF dan BE $\left(d_{v(s)}\right)$ sebagai berikut:

$$
d_{v(s)}=\frac{2}{3} x d_{v}=\frac{2}{3} \times 750 \mathrm{~mm}=500 \mathrm{~mm}
$$

Mencari besar sudut antara batang strut AB dan tie AF:

$$
\operatorname{arch} \tan \emptyset=\frac{\left(\mathrm{d}_{\mathrm{\gamma}(\mathrm{\theta})}\right.}{\mathbf{a}}=\frac{300}{470}=\operatorname{arch} \tan (1.0638)=46,771^{\circ}
$$

Setelah didapat nilai sudut dan tinggi $\mathrm{d}_{w}$, maka dapat dihitung jarak antara beban dan tumpuan terdekat (a): $470 \mathrm{~mm}$

Berdasarkan analisa rangka batang dari hasil perhitungan didapat:

$$
\begin{aligned}
& \sum^{\prime}\left(\mathrm{f}_{\mathrm{y}}\right)=\mathrm{p}-\mathrm{f}_{\mathrm{AB}}(\sin \theta) \\
& \mathrm{F}_{\mathrm{AD}}=\frac{\mathrm{p}}{(\sin \theta)}=\frac{28 \mathrm{~s}}{(\sin 46,771)}=391.149 \mathrm{kN} \\
& \sum(\mathrm{fr})=\mathrm{f}_{\mathrm{AF}}-\mathrm{f}_{\mathrm{AB}}(\cos \theta) \\
& \mathrm{F}_{A F}=\mathrm{f}_{\mathrm{AB}}(\cos \theta)=391,149(\cos 46,771)=267,904 \mathrm{kN}
\end{aligned}
$$

Gaya batang yang ada, digunakan untuk menghitung tinggi nodal 1 dan nodal 2 sebenarnya. Dalam proses ini dilakukan proses iterasi sampai pada keadaan 
dimana nilai sudut $\theta$ tidak lagi berubah secara signifikan. Dari konsep di atas, maka setelah dilakukan iterasi, didapat nilai tetap gaya-gaya batang sebagai berikut :

Gaya Tekan :

Batang BC dan DE $\quad=285,000 \mathrm{kN}$

Batang $\mathrm{AB}$ dan $\mathrm{EF} \quad=391,149 \mathrm{kN}$

Batang BE $\quad=267,904 \mathrm{kN}$

Batang CD $\quad=0$

Gaya Tarik :

Batang tarik $\mathrm{AF}=267,904 \mathrm{kN}$

Sudut iterasi $(\theta)=46,771^{\circ}$

b. Periksa daerah nodal dan kekuatan batang Strut

Untuk mencari kuat efektif $\left(f_{\mathrm{su}}\right)$ pada daerah nodal digunakan persamaan umum:

1. Cek nodal A

$$
\begin{aligned}
f_{v u} & =0,85 \times \beta_{n} \times f_{c} \\
\beta_{n} & =0,8 \text { (nodal jenis CCT) } \\
f_{w u} & =0,85 \times \beta_{n} \times f_{c} \\
& =0,85 \times 0,8 \times 40=27,2 \mathrm{MPa}
\end{aligned}
$$

2. Menghitung lebar daerah batang tarik $\left(\mathrm{W}_{16}\right)$

$$
\begin{aligned}
\mathrm{W}_{15} & =\frac{\mathrm{F}_{A F}}{\Phi \times b_{n \mathrm{~W}} \times \mathrm{F}_{\mathrm{N1}}} \leq 0,2 \mathrm{H} \\
& =\frac{267,904 \times 1000}{0,75 \times 300 \times 27,2} \leq 160 \mathrm{~mm} \\
& =43,775 \mathrm{~mm} \leq 160 \mathrm{~mm}
\end{aligned}
$$

Karena nilai $w_{16}$ tidak boleh kurang dari $160 \mathrm{~mm}$ dan nilai $w_{16}$ dinilai terlalu kecil untuk jarak di mana tulangan tarik ditempatkan, maka dipilih nilai $\mathrm{w}_{16} \approx 50 \mathrm{~mm}$ (pembulatan)

3. Mencari panjang pelat landasan pada tumpuan (lb)

$$
\mathrm{it}_{1} \approx \mathrm{w}_{1 \mathrm{e}} \approx 50 \mathrm{~mm}
$$

4. Mencari besar nilai tegangan yang terjadi pada dasar nodal $\left(f_{\mathrm{basic}}\right)$

$$
\begin{aligned}
& f_{\text {basic }}=\frac{R_{x}}{h_{w} \times 1 h}=\frac{285}{300 \times 50}=0,019 \mathrm{kNmm}^{2}=19 \mathrm{MPa} \\
& \varphi f_{\mathrm{wu}}=0,75 \times 27,20=20,40 \mathrm{MPa} \\
& \varphi \mathrm{f}_{\mathrm{wu}}>\mathrm{f} \text { (base) } \\
& 20,40 \mathrm{MPa}>19,00 \mathrm{MPa}(\mathrm{OK})
\end{aligned}
$$

5. Mengecek kekuatan batang strut $\mathrm{AB}$ dan $\mathrm{EF}$

$$
\begin{aligned}
& F_{\text {vu:strut })}=0,85 \times \beta_{z} \times f_{o}^{\prime}=\text { dimana } \\
& \beta_{3}=0.75 \\
& F_{\text {eu (strut) }}-0,85 \times 0,75 \times 10-25,50 \mathrm{MP}
\end{aligned}
$$

6. Mencari lebar strut pada nodal $1\left(\mathrm{w}_{\mathrm{5}}\right)$

$$
\begin{aligned}
\mathrm{w}_{31} & =\left(\mathrm{W}_{10}\right)(\cos \theta)+\left(1 \mathrm{~h}_{1}\right)(\sin \theta) \\
& =(50)\left(\cos 46,771^{\circ}\right)+(50)\left(\sin 46,771^{\circ}\right) \\
& =70,677 \mathrm{~mm}
\end{aligned}
$$




$$
\begin{aligned}
& \varphi \mathrm{F}_{\mathrm{zs}}=\varphi \times \mathrm{f}_{\mathrm{wu}} \times \mathrm{w}_{\mathrm{s}(1)} \mathrm{xb}_{w} \\
& =0,75 \times 25,50 \times 70,677 \times 300 \\
& \quad=405509,2875 \mathrm{~N}=405,509 \mathrm{kN} \\
& \varphi \mathrm{F}_{\mathrm{zs}}>\mathrm{F}_{\mathrm{u}(\text { strut })} 405,509>391,149(\mathrm{OK})
\end{aligned}
$$

7. Cek nodal B

$$
\begin{aligned}
& \beta_{\mathrm{n}}=1 \text { (nodal jenis CCC) } \\
& \begin{aligned}
\mathrm{F}_{\mathrm{cu} 2} & =0,85 \times \beta_{\mathrm{n}} \times \mathrm{f}_{\mathrm{o}} \\
& =0,85 \times 1 \times 40=34 \mathrm{MPa}
\end{aligned}
\end{aligned}
$$

8. Mencari jarak nodal $\mathrm{B}\left(\mathrm{W}_{12}\right)$

$$
\mathrm{W}_{12}=\frac{\mathrm{F}_{S F}}{\Phi \times \mathrm{b}_{w} \times \mathrm{f}_{\mathrm{U}(2)}}=\frac{267,904 \times 1000}{0,75 \times 300 \times 34}=\mathrm{W}_{12}=35,02 \mathrm{~mm}
$$

Sehingga jarak nodal $2\left(\mathrm{~W}_{12}\right)$ dipilih $35,02 \mathrm{~mm}$

9. Mencari nilai pelat landasan pada beban

$$
\mathrm{lb}_{2}=\frac{2}{3} \times \mathrm{w}_{\mathrm{s}}=\frac{2}{3} \times 70,677=47.12 \mathrm{~mm}
$$

Maka nilai $\mathrm{lb}_{2}$ dipilih 47,12 mm

10. Mencari besar nilai tegangan yang terjadi pada nodal $2\left(f_{(\operatorname{mid} d \mathrm{~d})}\right)$

$$
\begin{aligned}
& f_{\text {middl }}=\frac{F_{B C}}{b_{w i} \times 1 b_{2}}=\frac{295}{300 \times 47,12}=0,02016 \mathrm{kN} / \mathrm{mm}^{2}=20,16 \mathrm{MPa} \\
& \varphi f_{\mathrm{wu}(2)}=0,75 \times 34=25,5 \mathrm{MPa} \\
& \varphi f_{\mathrm{wa}(2)}>f_{\mathrm{mid}} \mathrm{dl} \\
& 25,5 \mathrm{MPa}>20,16 \mathrm{MPa}(\mathrm{OK})
\end{aligned}
$$

11. Mencari nilai gaya horizontal tegak lurus $w_{12}$

$$
\begin{aligned}
p_{\mathrm{h}} & =f_{\mathrm{AB}} \times \cos \theta \\
& =391,149 \times 0,6849=267,904 \mathrm{kN}
\end{aligned}
$$

12. Cek tegangan pada bidang vertikal dan bagian kiri nodal $2\left(f_{(\mathrm{vart}, \mathrm{fass})}\right)$

$$
\begin{aligned}
& \left(f_{\text {(wort, fass })}\right) \quad=\frac{\mathrm{P}_{\mathrm{h}}}{\mathrm{w}_{12} \pi v_{\mathrm{w}}}<\mathrm{F}_{\mathrm{mm} \text { ? }} \\
& =\frac{267,904}{35,02 \times 300}<34,00 \\
& =25,50 \mathrm{MPa}<34 \mathrm{MPa}(\mathrm{OK})
\end{aligned}
$$

13. Menentukan lebar strut pada nodal 2

$$
\begin{aligned}
& \left.\mathrm{w}_{\mathrm{z}(\operatorname{mid} d \mathrm{l})}\right)\left(\mathrm{w}_{12}\right)(\cos \theta)+\left(1 \mathrm{~b}_{2}\right)(\sin \theta) \\
& \left.=(35,02)\left(\cos 46,771^{\circ}\right)+(35,02)\left(\sin 46,771^{\circ}\right)\right) \\
& =49,502 \mathrm{~mm}
\end{aligned}
$$

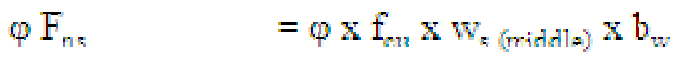

$$
\begin{aligned}
& =0,75 \times 34 \times 49,502 \times 300 \\
& =395690,3 \mathrm{~N}=395,690 \mathrm{kN} \\
& \varphi F_{p z}>F_{u[s \text { thut }]} \quad 395,690>391,149(\mathrm{OK})
\end{aligned}
$$

14. Cek nodal C

$$
\begin{aligned}
& \beta_{\mathrm{n}}=1 \text { (nodal jenis CCC), } \mathrm{F}_{\text {cuj }}=0,85 \times \beta_{\mathrm{n}} \times \mathrm{f}_{\mathrm{a}} \\
& \mathrm{lb}_{(3)}=\mathrm{lb}_{(2)}=47,12 \mathrm{~mm}
\end{aligned}
$$

15. Mencari besar nilai tegangan yang terjadi pada dasar nodal ( $\left.f_{(\text {top })}\right)$ 


$$
\begin{aligned}
& \mathrm{f}_{(\mathrm{top})}=\frac{\mathrm{p}}{\mathrm{b}_{w} \times 1 \mathrm{~b}_{2}}=\frac{285 \times 1000}{300 \times 47,12}=20,161 \mathrm{MPa} \\
& \varphi \mathrm{f}_{\text {vu3 } 3}=0, / 5 \times 34=25,5 \mathrm{MPa} \\
& \varphi \mathrm{f}_{\mathrm{cu3}}>\mathrm{f}_{(\mathrm{tg})} \\
& 25,5 \mathrm{MPa}>20,161 \mathrm{MPa}(\mathrm{OK})
\end{aligned}
$$

16. Mengecek kekuatan batang strut $\mathrm{BC}$ dan $\mathrm{CD}$

$$
\begin{aligned}
& F_{\text {eu (strut) }}-0,85 \times \beta_{\mathrm{n}} \times \mathrm{f}_{\mathrm{O}}\left(\mathrm{F}_{\mathrm{n}}-0,75\right) \\
& F_{\text {cu (strut) }}=0,85 \times 0,75 \times 40=25,5 \mathrm{MPa}=25,500 \mathrm{kN} \\
& \varphi F_{\mathrm{n}:}=\varphi \times \mathrm{F}_{\mathrm{su} \text { (atrut: }} \times \mathrm{lb}_{3} \times \mathrm{b}_{\mathrm{w}} \\
& =0,75 \times 25,5 \times 47,12 \times 300 \\
& =270351 \mathrm{~N}=270,351 \mathrm{kN} \\
& \varphi \mathrm{F}_{\mathrm{ng}}>\mathrm{F}_{\mathrm{cu} \text { (atrut) }} \\
& 270,351 \mathrm{kN}>25,500 \mathrm{kN}(\mathrm{OK})
\end{aligned}
$$

17. Pengecekan kembali sudut dan gaya batang yang bekerja

Setelah dilakukan pengecekan daerah nodal dan strut, didapat ketinggian nodal 1 (lebar tie) maka, nilai $d_{v}$ adalah sebagai berikut:

$$
\begin{aligned}
d_{v} & =H-\frac{(t . n o d a l ~ A+t . n o d a l ~ C)}{2} \\
& =800-\frac{(50+50)}{2} \\
& =750 \mathrm{~mm}
\end{aligned}
$$

Untuk mencari nilai sudut yang dibentuk truss, dicari jarak antara batang AF dan BE ( $\left.\mathrm{d}_{\mathrm{w}}\right)$ sebagai berikut:

$$
\begin{aligned}
\left(d_{v(s)}\right) & =\frac{2}{3} \times d_{v} \\
& =\frac{2}{3} \times 750=500 \mathrm{~mm}
\end{aligned}
$$

Jarak antara beban dan tumpuan terdekat

(a) $=470 \mathrm{~mm}$

Mencari besar sudut antara batang strut $\mathrm{AB}$ dan tie $\mathrm{AF}$ :

$$
\theta=\frac{\left(d v_{0}\right)}{a}=\arctan \left(\frac{300}{470}\right)=\arctan (1,0638)=46,771^{*}
$$

Berdasarkan analisa rangka batang dari hasil perhitungan didapat:

Gaya Tekan :

$$
\begin{array}{ll}
\text { Batang BC dan DE } & =285,00 \mathrm{kN} \\
\text { Batang AB dan EF } & =391,149 \mathrm{kN} \\
\text { Batang CD } & =0 \\
\text { Batang BE } & =267,904 \mathrm{kN}
\end{array}
$$

Gaya Tarik :

$$
\begin{array}{ll}
\text { Batang tarik AF } & =267,904 \mathrm{kN} \\
\text { Sudut iterasi }(\theta) & =46,771^{\circ}
\end{array}
$$

Dengan demikian gaya-gaya batang dan sudut rangka $(\theta)$ ini sudah tidak mengalami perubahan secara signifikan dengan gaya batang asumsi sebelumnya. Iterasi tidak perlu lagi dilakukan.

c. Periksa gaya geser maksimum yang diizinkan balok tinggi

Menurut (ACI318, 2019) untuk menentukan batas gaya geser yang diizinkan pada balok tinggi yaitu sebagai berikut: 


$$
\begin{aligned}
& \mathrm{d}=\mathrm{h}-\frac{\mathrm{w}_{16}}{2}=800-\frac{50}{2}=775 \mathrm{~mm} \\
& \mathrm{l}_{\mathrm{n}}=5900 \mathrm{~mm}
\end{aligned}
$$

Rumus yang dipakai untuk menentukan gaya geser yang diizinkan:

$$
\begin{aligned}
& \mathrm{V}_{\mathrm{u}}<\varnothing\left|\frac{2}{3}\left(10+\frac{\mathrm{l}_{\mathrm{n}}}{\mathrm{d}}\right) \sqrt{\mathrm{f}_{\mathrm{v}} \mathrm{b}_{w} \mathrm{~d}}\right| \\
& 285000 \mathrm{~N}<0,85\left|\frac{2}{3}\left(10+\frac{5900}{775}\right) \sqrt{40 \times 300 \times 775}\right| \\
& 285000 \mathrm{~N}<17714130,52 \mathrm{~N}(\mathrm{OK})
\end{aligned}
$$

d. Pilih penulangan untuk batang tie $\mathrm{A}-\mathrm{F}$

$$
A_{s_{\text {yariu }}}=\frac{F_{A H}}{\Phi \times f_{y}}=\frac{267,901 \times 1000}{0,75 \times 400}=894,013 \mathrm{~mm}^{2}
$$

Berdasarkan (ACI318, 2019) bahwa penulangan minimum $\mathbf{A}_{z \text { gsh }}$ pada daerah tarik tidak kurang dari :

$$
\begin{gathered}
0,04\left(\frac{f_{v}}{f_{y}}\right) b_{w} d=0,04\left(\frac{40}{400}\right) \times 300 \times 775 \\
=930 \mathrm{~mm}^{2}
\end{gathered}
$$

Maka dipilih $A_{1}$ p: $=930 \mathrm{~mm}^{2}$

$$
\text { Jumlah tulangan }=\left(\frac{\mathrm{A}_{5 \text { perlu }}}{\frac{1}{4} \pi \mathrm{D}^{2}}\right)=\left(\frac{930}{\frac{1}{4} \times 3,14 \times 16^{2}}\right)=4,63 \approx 5 \text { tulangan }
$$

Sehingga luas tulangan $A_{3}$ terpasang menjadi $=5 \times 201,06=1005,3 \mathrm{~mm}^{2}$

Maka, dipakai tulangan longitudinal 5D16

Cek batang tarik :

$$
\begin{aligned}
& \mathrm{T}_{\mathrm{u}}=\Phi \times \mathrm{A}_{\mathrm{s}} \times \mathrm{f}_{\mathrm{y}} \\
& =0,8 \times 1005,3 \times 400 \\
& =321696 \mathrm{~N}=321,696 \mathrm{kN} \\
& \mathrm{T}_{\mathrm{u}}>\mathrm{F}_{16} \\
& 321,696 \mathrm{kN}>267,904 \mathrm{kN}(\mathrm{OK})
\end{aligned}
$$

e. Menghitung jarak bidang runtuh atau critical section $\left(1_{\mathbf{a}}\right)$ dari perletakan untuk menentukan panjang pengangkuran $\left(1_{\mathrm{dh}}\right)$

1. Mengecek jarak critical section

$$
\begin{aligned}
1_{3} & =\left(\frac{w_{10}}{2}\right) /(\tan \theta) \\
& =(50,00) /(\tan 46,771) \\
& =23,5 \mathrm{~mm}
\end{aligned}
$$

2. Mengecek panjang penyaluran dan rumus berdasarkan(SNI03-2847, 2019)

$$
\begin{aligned}
& L_{a h}=\frac{f_{y} \times d_{b}}{5,4 x \sqrt{f_{\varepsilon}}}>8 d_{2} \\
& =\frac{400 \times 16}{5,4 \pi \cdot 40} \\
& \mathrm{~L}_{\mathrm{gh}}=187,394>128 \mathrm{~mm}(\mathbf{O K})
\end{aligned}
$$


f. Beri penulangan minimum pada strut $\mathrm{A}-\mathrm{B}$

1. Menghitung besar sudut vertikal dengan aksis pada strut $1-2$

$$
\gamma_{\text {(tulangan vatikal) }}=46,77
$$

Spasi maksimum $\left(\mathrm{SV}_{\text {wan }}\right)=\frac{\mathrm{d}}{5}$ atan $300 \mathrm{~mm}$ (diambil yang tarkecil)

$$
=150 \mathrm{~mm}
$$

Sehingga spasi maksimum untuk tulangan vertikal adalah $150 \mathrm{~mm}$

Maka, dipakai tulangan vertikal Ø $10-150 \mathrm{~mm}$

$$
\begin{aligned}
\rho_{y} \quad & =\frac{4 \pi t^{2}}{s_{7} b_{y}}>0,0025 \\
& =\frac{4 \pi 3,14 \pi 2 z^{2}}{150 \pi 300}>0,0025 \\
& =0,1744>0,0025(\mathrm{OK}) \\
\rho_{y} \sin \gamma= & 0,1744 \sin 46,77^{\circ}=0,1271
\end{aligned}
$$

2. Menghitung besar sudut aksis pada strut $1-2$ dan penulangan horisontal

$$
\gamma_{\text {(tulangan vatikal) }}=90,00-46,77=42,23
$$

Spasi maksimum $\left(\mathrm{Sh}_{\max }\right)=\frac{\mathrm{d}}{\sigma_{i}}$ atau $300 \mathrm{~mm}($ diambil yang terkecil $)=130$ mm (agar persamaan $\rho_{n}$ memenuhi)

Menentukan batas gaya geser yang diizinkan (ACI318, 2019) :

$$
\begin{aligned}
& \mathrm{d}=\mathrm{h}-\frac{w_{\mathrm{M}}}{2} \text {, jadi : } \\
& \mathrm{p}_{\mathrm{h}}=\frac{2 \pi \mathrm{r}^{2}}{\mathrm{~s}_{\mathrm{h}} \mathrm{b}_{\mathrm{w}}}>0,0015 \\
& =\frac{2 \times 3,14 \times 25^{2}}{130 \times 300}>0,0015 \\
& =0,1006>0,0015(\mathrm{OK}) \\
& \rho_{1} \sin \gamma-0,1006 \sin 12,23^{\circ}-0,0676 \\
& \text { Jumlah tulangen }(\mathrm{n})=\left(\frac{\mathrm{H}-2 \mathrm{~s}-2 \mathrm{D} \text { sengkang vertikal }}{\mathrm{sh}_{\max }}\right) \times \text { jumlah kaki } \\
& =\left(\frac{800-2 \times 50-2 \times 10}{130}\right) \times 2 \\
& =10 \text { buah }
\end{aligned}
$$

Total $A_{\mathrm{s}}$ perlu $=n \times A_{3} 1$ tulangan

$$
=(10) \times\left(\frac{\pi \times 10^{2}}{4}\right)=768,40 \mathrm{~mm}^{2}
$$

Maka dipakai tulangan horizontal $10 \varnothing 10$

g. Cek persyaratan (ACI318, 2019)

Dengan rumus umum yang ditentukan oleh(ACI318, 2019), ditentukan sebagai berikut :

$$
\begin{aligned}
\sum(\mathrm{i})(\sin \gamma) & >0,003 \\
(\mathrm{\rho i})(\sin \gamma) & =(0,001379+0,00246)>0,003 \\
= & 0,0038>0,003(\mathrm{OK})
\end{aligned}
$$

Detail balok tinggi yang telah didesain disketsa dalam gambar berikut : 


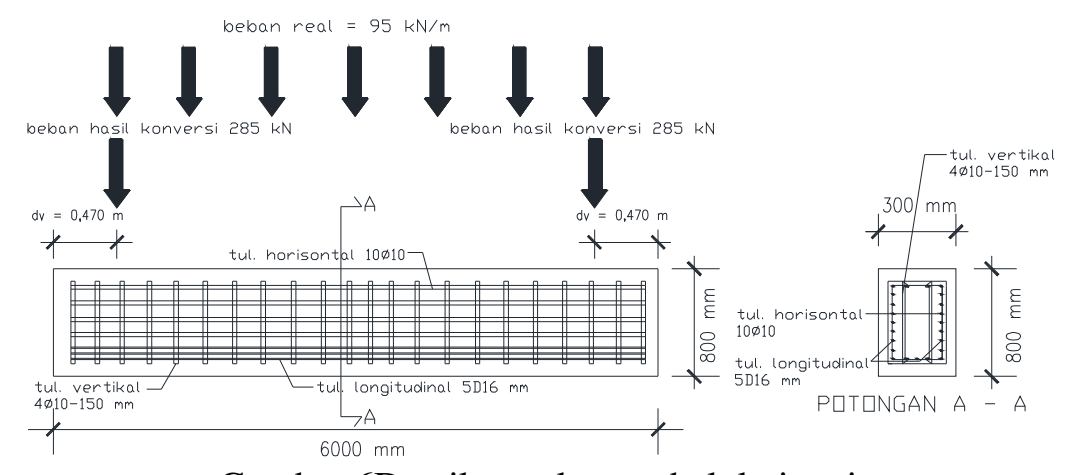

Gambar 6Detail penulangan balok tinggi

Berdasarkan hasil dan pembahasan, dapat disimpulkan pada balok bentang $6000 \mathrm{~mm}$ dengan tinggi $800 \mathrm{~mm}$ bahwa semakin besar nilai rasio bentang balok tinggi $(\mathrm{L} / \mathrm{H})$, maka semakin besar pula luasan tulangan yang diperlukan baik tulangan longitudinal, tulangan vertikal, maupun tulangan horizontal. Luas tulangan yang dibutuhkan oleh tulangan vertikal yang lebih besar dari pada tulangan longitudinal menandakan bahwa pada balok tinggi, keruntuhan yang terjadi dominan diakibatkan oleh gaya geser seperti pada penelitian (Tasenhod and Teerawong, 2014) yang dapat memprediksi keruntuhan dari gaya geser balok tinggiyang menggunakan model strut and tie. Metode strut and tie juga merupakan metode yang fleksibel dalam memprediksi keruntuhan pada balok tinggi beton bertulang, pernyataan ini diungkapkan pada penelitian (Gong and Su, 2013). Untuk mempelajari keruntuhan balok tinggi dengan metode strut and tiejuga dapat menggunakan analisa numerik metode elemen hingga seperti pada penelitian (Pranata and Suryoatmono, 2019). Dari gambar penulangan dapat dilihat bahwa tulangan horizontal yang dibutuhkan adalah 10®10, untuk tulangan longitudinal 5D16 mm serta untuk tulangan vertikalnya menggunakan $4010-$ $150 \mathrm{~cm}$. Dengan menggunakan metode strut and tie model, maka diperoleh hasil tegangan sebesar 16,978 MPa pada dasar nodal. Sedangkan pada penelitian sebelumnya yaitu (Afrizal, 2011)yang merencanakan balok tinggi dengan menggunakan alternatif bearing plate, untuk tegangan yang terjadi di bawah bearing plate yaitu 6,13 MPa. Penelitian kali ini merupakan alternatif dari penelitian Yuzuar Afrizal, namun untuk bearing plate di penelitian kali ini ditiadakan dan dengan bearing plate yang ditiadakan maka tegangan yang dihasilkan menjadi hampir 3 kali lipat dibanding balok tinggi yang menggunakan bearing plate.

\section{Kesimpulan dan Saran}

\subsection{Kesimpulan}

Dari hasil penelitian di atas dapat disimpulkan bahwa berdasarkan rangka batang yang terbentuk, sudut arah tegangan antara batang strut and tie yang besarnya dipengaruhi oleh nilai rasio L/H. Nilai rasio L/H mempengaruhi besar luas tulangan, baik itu tulangan longitudinal, tulangan vertikal, maupun tulangan horizontal. Luas tulangan yang dibutuhkan oleh tulangan vertikal yang lebih besar dari pada tulangan longitudinal menandakan bahwa pada balok tinggi, keruntuhan 
yang terjadi dominan diakibatkan oleh gaya geser. Analisis yang didasarkan pada model strut and tie merupakan motode yang paling rasional dan akan memberikan penulangan yang efisien. Balok tinggi yang dirancang tanpa menggunakan bearing plate akan lebih besar dalam menghasilkan tegangan.

\subsection{Saran}

Perlu dilakukan penelitian lebih lanjut berkaitan dengan variasi dimensi penampang balok tinggi yang digunakan serta metode strut and tie pada balok tinggi dengan perletakan lebih dari 2 tumpuan, variasi pembebanan selain beban merata dan beban terpusat di tengah bentang, selain itu dapat pula digunakan pemodelan numerik untuk perencanaan balok tinggi, serta perlu dilakukan penelitian strut and tie pada elemen yang berbeda, seperti pada balok konsol, balok $\mathrm{T}$, atau dinding geser.

\section{Ucapan Terima Kasih}

Ucapan terima kasih disampaikan kepada semua dosen yang telah berperan dalam membantu memeriksa penulisan jurnal ini di Universitas Diponegoro Semarang, Provinsi Jawa Tengah, sehingga ide-ide yang penulis harapkan dapat dituangkan dalam bentuk tulisan dan diinformasikan kepada peneliti-peneliti balok tinggi dengan metode strut and tie di Indonesia.

\section{Daftar Kepustakaan}

ACI318 (2019) 318-19 Building Code Requirements for Structural Concrete and Commentary, 318-19 Building Code Requirements for Structural Concrete and Commentary. doi: 10.14359/51716937.

Afrizal, Y. (2011) 'Strut and Tie Model Sebagai Alternatif Perancangan Struktur Beton Bertulang', Inersia Jurnal teknik Sipil, 3(1), pp. 39-44. Available at: https://ejournal.unib.ac.id/index.php/inersiajurnal/article/view/6704.

Agus Sugianto, A. M. I. (2014) 'Perilaku Penggunaan Model Struktur Penunjang Dan Pengikat ( Strut-and-Tie Model ) Pada Balok Beton Mutu Normal Untuk Tinggi', pp. 521-534.

Gong, H. and Su, M. (2013) 'Introduction of the application of strut-and-tie model in concrete deep beams', 674, pp. 704-708. doi: 10.4028/www.scientific.net/AMR.671-674.704.

Misbakhul Munir, Zulfikar Djauhari, I. R. S. J. (2014) 'Analisa Balok Tinggi Beton Bertulang Dengan Menggunakan Metode', pp. 1-15.

Pranata, Y. A. and Suryoatmono, B. (2019) 'Pemodelan Numerik Perilaku Keruntuhan Balok Tinggi Beton Bertulang', Jurnal Teknik Sipil, 6(1), pp. 42-62. doi: 10.28932/jts.v6i1.1326. 
Saputra, C. Y. and Satuan (2012) 'Model Perancangan Disturbed Region Balok Girder Jembatan Dengan Menggunakan Metoda Strut AND Tie', 4, pp. 8496.

Simatupang, P. H. and Cendana, U. N. (2017) 'Perancangan Balok Tinggi Beton Bertulang Yang Memikul Beban Merata Dengan Menggunakan Sap 2000', (November).

SNI03-2847 (2019) SNI 03-2847:2019 Persyaratan Beton Struktural Untuk Bangunan Gedung Dan Penjelasan Sebagai Revisi Dari Standar Nasional Indonesia 2847 $\square:$ 2013, Badan Standarisasi Nasional.

Tasenhod, P. and Teerawong, J. (2014) 'Shear Strength Prediction of Reinforced Concrete Deep Beams Using Strut-and-Tie Model', 932, pp. 468-472. doi: 10.4028/www.scientific.net/AMR.931-932.468. 